\title{
The Relationship between Spiritual Intelligence with Mental Health and Job Burnout (Case Study: Rural Cooperative Organization of Golestan Province)
}

\author{
Naghi Tabarsa ${ }^{1}$, Hamid Reza Jalaei ${ }^{1 *}$ \\ ${ }^{1}$ Department of Management, Aliabad Katoul Branch, Islamic Azad University, Aliabad Katoul, IRAN
}

*Corresponding Author: hr_jalaei@yahoo.com

Citation: Tabarsa, N. and Jalaei, H. R. (2017). The Relationship between Spiritual Intelligence with Mental Health and Job Burnout (Case Study: Rural Cooperative Organization of Golestan Province). Dutch Journal of Finance and Management, 1(2), 46. https:/ / doi.org/10.29333/djfm/5822

Published: September 14, 2017

\begin{abstract}
The purpose of this study was to investigate the relationship between spiritual intelligence and burnout and mental health staff of rural cooperatives organization of Golestan province. This study is an applied research and descriptive correlational survey. To collect field data in this study, standard questionnaires: a) a standard questionnaire to measure spiritual intelligence David the King; b) mental health assessment questionnaire (GHQ-28) Goldberg and d) we applied two standard questionnaires for assessment of burnout among 165 rural cooperatives in Golestan province were distributed to employees. Data analysis was performed using descriptive and inferential statistics SPSS19 software. Pearson correlation coefficient was used to test the hypotheses. The findings show that a positive correlation between spiritual intelligence and mental health and there is a significant and negative correlation between spiritual intelligence and depression and there is a significant job.
\end{abstract}

Keywords: spiritual intelligence, mental health, job depression

\section{INTRODUCTION}

Mental health is generally used to refer to someone who is a high level of emotional and behavioral adjustment and adaptation, rather than someone who is not mentally ill. Great Dictionary "Larousse" also mental health and mental capacity to work effectively coordinated welcoming, flexibility and the ability to maintain your balance is defined in difficult situations (Emmons, 1999). In a general classification of mental illnesses could be concluded that health information is presented three different models, "bio" (medical) "bio-psycho-social model (model system) and "mental health promotion model" "bio", believed to detect or identify possible physical causes of mental disorders (ibid) (Ghorbani, 2004). From the perspective of "bio-psycho-social model", human behavior in general, a "system" considered where various factors interact with each other. With this systemic perspective, it will be seen how different biological and psychological factors and social factors affect people on the other. "Upgrade version" broadly to aspects of environmental, social and economic analysis of mental health care and mental health as a pivotal issue in human life thinks. In recent years spirituality as an important aspect of humanitarian action, which is related to the reliability of health and healing is considered. Although there are similarities spirituality with religion, but the concept is broader and broader than religion. Spiritual intelligence, spirituality and intelligence structures within a new structure combines (ibid) and at the same time as the human capacity and experience and integrated communication between us and the world in which we live, have been described. In the early twentieth century intelligence as a cognitive ability by "Alfred Binet" was introduced (Wong et al., 2010). Sternberg (1997), with an emphasis on biological and evolutionary aspects of intelligence suggests that 


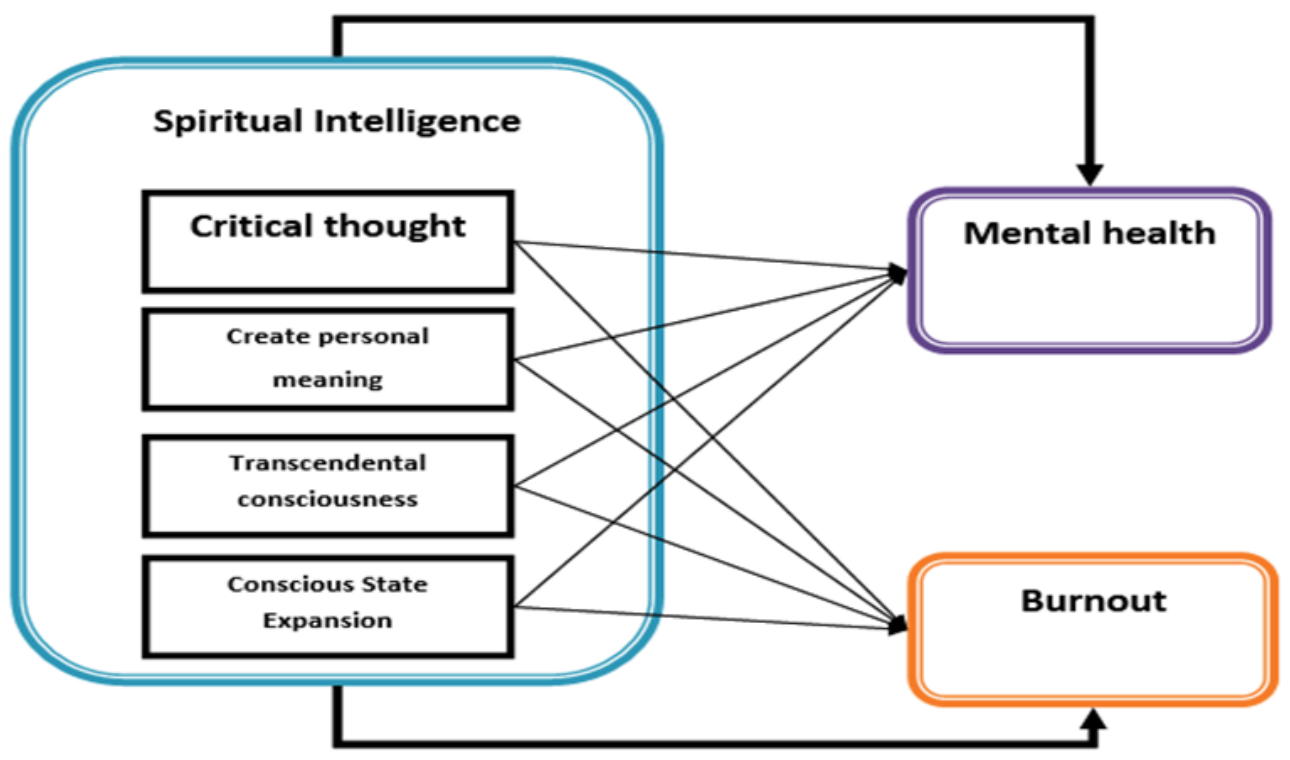

Figure 1. Conceptual model

intelligence means mental abilities needed for adaptation. To determine the intelligence of theoretical frameworks have been offered so far, such as "intelligence" systems based on neural functioning (IQ, emotional intelligence and spiritual intelligence) noted (yang, 2006). Spiritual intelligence, as opposed to general intelligence and, unlike computers, it also has a higher emotional intelligence in mammals, there are specific exclusively man. The remarkable thing is that to achieve success in life, it is not necessary that people just have to be a high general intelligence, emotional intelligence and spiritual intelligence is high, but what is necessary (Harrisson et al., 2002). Based on the results available, it seems that people have when dealing with the intellectual trends of injury, better responses to their status and position of the pressure better production run and with less depression. Burnout is a professional risk by reducing the amount of physical and mental energy on staff, as well. Burnout reduces the effectiveness and efficiency of human resources and consequently loss of productivity in organizations (Hurst et al., 2007). AMRAAM believes that in order to improve the performance of employees, spiritual intelligence can have a successful and efficient job management have played a role, so that a person's spiritual intelligence not only changed the perception of problems and difficult situations Job Therefore, it makes a person feel compassion toward others has become more and more endurance in the face of adversity and show business environment (Kobassa, 1982). So focus on spiritual intelligence employees of burnout can be prevented or greatly reduced. Spiritual intelligence collection capabilities of mental adaptation is based on the spiritual and transcendental aspects, the reality, especially those aspects related to the nature of the individual, personal meaning, transcendence and expanded states of consciousness (Lambert et al, 2007). These processes have an adaptive role in facilitating individual meaning-making, problem-solving and abstract reasoning. According to King, the SQ has the following dimensions (Mabe et al., 2004): 1) critical thinking about issues are: the capacity to think critically about the metaphysical and existential issues, including the existence, truth, world, time, space and death and 2) create a personal meaning: the ability to use physical and psychological experience to create personal meaning and purpose; 3) higher awareness: the ability to identify aspects of the transcendental self, others and the world using consciousness; 4) creating the position of consciousness: the ability to enter and exit higher spiritual situations such deep thought, prayer and meditation (King, 2008). To understand the meaning of life and solve problems not only intelligent, rational and emotional value used, but should be used by intelligence beyond conventional intelligences that this is in the form of "spiritual intelligence" is mentioned. The findings also showed that spiritual intelligence and emotional exhaustion, depersonalization, and reduced personal performance have a significant negative relationship. For this reason, the main issue that was investigated in this research is to identify the relationship between intellectual intelligence mental health and burnout among staff in Golestan province is rural cooperatives.

\section{Conceptual Model}

In order to plan for the implementation of these model used to study the relationship between intellectual intelligence mental health and burnout among staff shows. Figure 1 shows the components of research in the form of conceptual model. 


\section{Hypotheses}

\section{Main hypothesis}

1) There is a significant correlation between spiritual intelligence and mental health staff of rural cooperative Golestan

2) There is a significant correlation between spiritual intelligence and burnout among staff of rural cooperative Golestan

\section{Sub-research hypotheses}

1) There is a significant relationship between the components of critical thought and mental health staff of rural cooperative Golestan

2) There is a significant relationship between the components to create personal meaning and mental health staff of rural cooperative Golestan

3) There is a significant relationship between the components of transcendental consciousness and mental health staff of rural cooperative Golestan

4) There is a significant relationship between the components of consciousness and mental development of the Rural Cooperative Organization of Golestan province

5) There is a significant relationship between the components of critical thought and burnout among staff of rural cooperative Golestan

6) There is a significant relationship between the components to create personal meaning and burnout among staff of rural cooperative Golestan

7) There is a significant relationship between the components of transcendental consciousness and burnout among staff of rural cooperative Golestan

8) There is a significant relationship between knowledge and the development component of burnout among staff of rural cooperative Golestan

\section{METHODOLOGY}

The method of research, survey and in terms of purpose, is applied. The population of the investigation, managers and employees and Rural Cooperatives Organization of Golestan province, which is a total number of 269 people. Considering the sample size of 158 patients was determined by Morgan. In this study, for the purpose of gathering data from three questionnaires: a) a standard questionnaire to measure spiritual intelligence David B. King; b) mental health assessment questionnaire (GHQ-28) Goldberg \& D) standard questionnaire.

\section{RESULTS}

\section{Descriptive Statistics}

The study sample included 139 people, equivalent to $84 \%$ of men and 26 are women 16 percent. In terms of literacy and education sample 22 to 13 percent have an associate degree and 61 degree and 64 equivalents of $37 \%$ to $39 \%$ to $11 \%$ of the respondents had a bachelor's and 18 master's degree are. As well as 25 to $15 \%$ with a history of less than 5 years, 46 patients (28\%) of 5 to 10 years, 35 or 21 per cent of 10 to 15 years, $n=3924 \% 15$ to 20 years and 20 equal to $12 \%$ over 20 years of service.

\section{Hypotheses Analysis}

Table 1 shows the results of testing hypotheses. 
Table 1. Descriptive statistics of variables

\begin{tabular}{|c|c|c|c|}
\hline Hypotheses & Statistical Methods & Result & Interpretation of results \\
\hline $\begin{array}{l}\text { The main hypothesis } \\
\text { first }\end{array}$ & $\begin{array}{l}\text {-Test for normality } \\
\text {-Pearson correlation coefficient }\end{array}$ & $\begin{array}{l}\text { Accepted } \\
\text { hypothesis }\end{array}$ & $\begin{array}{l}\text { There is a significant relationship between spiritual intelligence } \\
\text { and mental health staff of rural cooperative Golestan at } 95 \%\end{array}$ \\
\hline $\begin{array}{l}\text { The first sub- } \\
\text { hypothesis test }\end{array}$ & $\begin{array}{l}\text { - Test for normality } \\
\text { - Pearson correlation coefficient. }\end{array}$ & $\begin{array}{l}\text { Accepted } \\
\text { hypothesis }\end{array}$ & $\begin{array}{l}\text { There is a significant relationship between critical thought and } \\
\text { mental health staff of rural cooperative Golestan at } 95 \%\end{array}$ \\
\hline $\begin{array}{l}\text { The second sub- } \\
\text { hypothesis test }\end{array}$ & $\begin{array}{l}\text { - Test for normality } \\
\text { - Pearson correlation coefficient. }\end{array}$ & $\begin{array}{l}\text { Accepted } \\
\text { hypothesis }\end{array}$ & $\begin{array}{l}\text { There is a significant relationship between the creation of } \\
\text { personal meaning and mental Rural Cooperative Organization of } \\
\text { Golestan province at } 95 \%\end{array}$ \\
\hline $\begin{array}{l}\text { The third sub- } \\
\text { hypothesis test }\end{array}$ & $\begin{array}{l}\text { - Test for normality } \\
\text { - Pearson correlation coefficient. }\end{array}$ & $\begin{array}{l}\text { Accepted } \\
\text { hypothesis }\end{array}$ & $\begin{array}{l}\text { There is a significant relationship between higher consciousness } \\
\text { and mental health staff of rural cooperative Golestan at } 95 \%\end{array}$ \\
\hline $\begin{array}{l}\text { The fourth sub- } \\
\text { hypothesis test }\end{array}$ & $\begin{array}{l}\text { - Test for normality } \\
\text { - Pearson correlation coefficient. }\end{array}$ & $\begin{array}{l}\text { Accepted } \\
\text { hypothesis }\end{array}$ & $\begin{array}{l}\text { There is a significant relationship between mental health } \\
\text { awareness and the development of rural cooperative staff } \\
\text { Golestan province at } 95 \%\end{array}$ \\
\hline $\begin{array}{l}\text { The main hypothesis } \\
\text { Second }\end{array}$ & $\begin{array}{l}\text { - Test for normality } \\
\text { - Pearson correlation coefficient. }\end{array}$ & $\begin{array}{l}\text { Accepted } \\
\text { hypothesis }\end{array}$ & $\begin{array}{l}\text { There is a significant relationship between spiritual intelligence } \\
\text { and job burnout Rural Cooperative Organization of Golestan } \\
\text { province at } 95 \%\end{array}$ \\
\hline $\begin{array}{l}\text { The fifth sub- } \\
\text { hypothesis test }\end{array}$ & $\begin{array}{l}\text { - Test for normality } \\
\text { - Pearson correlation coefficient. }\end{array}$ & $\begin{array}{l}\text { Not } \\
\text { Accepted } \\
\text { hypothesis }\end{array}$ & $\begin{array}{l}\text { There is not a significant relationship between critical thought and } \\
\text { job burnout Rural Cooperative Organization of Golestan } \\
\text { province at } 95 \%\end{array}$ \\
\hline $\begin{array}{l}\text { Sixth sub-hypothesis } \\
\text { test }\end{array}$ & $\begin{array}{l}\text { - Test for normality } \\
\text { - Pearson correlation coefficient. }\end{array}$ & $\begin{array}{l}\text { Accepted } \\
\text { hypothesis }\end{array}$ & $\begin{array}{l}\text { There is a significant relationship between the creation of } \\
\text { personal meaning and job burnout Rural Cooperative } \\
\text { Organization of Golestan province at } 95 \%\end{array}$ \\
\hline $\begin{array}{l}\text { Seven sub-hypothesis } \\
\text { test }\end{array}$ & $\begin{array}{l}\text { - Test for normality } \\
\text { - Pearson correlation coefficient. }\end{array}$ & $\begin{array}{l}\text { Accepted } \\
\text { hypothesis }\end{array}$ & $\begin{array}{l}\text { There is a significant relationship between higher consciousness } \\
\text { and job burnout Rural Cooperative Organization of Golestan } \\
\text { province at } 95 \%\end{array}$ \\
\hline $\begin{array}{l}\text { Eight sub-hypothesis } \\
\text { test }\end{array}$ & $\begin{array}{l}\text { - Test for normality } \\
\text { - Pearson correlation coefficient. }\end{array}$ & $\begin{array}{l}\text { Accepted } \\
\text { hypothesis }\end{array}$ & $\begin{array}{l}\text { There is a significant relationship between mental health } \\
\text { awareness and job burnout Rural Cooperative Organization of } \\
\text { Golestan province at } 95 \%\end{array}$ \\
\hline
\end{tabular}

\section{CONCLUSION}

The findings show that between spiritual intelligence and mental health staff of rural cooperative relations between Iran and negative, so that no matter how spiritual intelligence is high, employees will experience fewer psychological problems and in front of more mental health will (McEwan, 2004). Of the four mental health scale, the scale of the strongest awareness and show the highest correlation with spiritual intelligence. In other words, the people of the state of higher consciousness, the mental health increases (Mitchel et al, 2004). The findings of the Smith study, Zohar and Marshall and Aymvnz who believe that spiritual intelligence to create insight, meaningful life, adaptability and problem solving will correspond. Second, the correlation between the transcendental consciousness and mental health. These findings are consistent with studies of Oswald and James and colleagues. Spiritual intelligence is the ability to give people the dynamism and vitality of its spiritual resources to keep calm (Smucker, 1998; Sortet et al, 1996).

The entry into professions and occupations spirituality nascent phenomenon that can have a positive impact on improving the performance and competence of individuals and organizations is improving (Vogt et al, 2008; Walker; 2006; Walt et al, 2006); So we can conclude that the influence of spirituality on flexibility and adaptability and improve the quality of working life and affect their performance and avoid burnout. Since the spiritual intelligence of burnout and its dimensions are concerned, people with high spiritual intelligence holistic vision of life and take advantage of the virtues and positive, more ability to solve problems and adapt to their working conditions. Considering the fact that many staff of rural cooperative Golestan province with a lot of difficulties and challenges encountered in the workplace, spiritual intelligence can improve their performance and enhance the quality of work, so the promotion of spiritual intelligence, and continuous education served Recommended.

\section{Proposals in Line with Results}

- Thinking about the signs of God in the range is: attention to the signs of God's mercy in the hearts alive, and he reminds us, and finally, the love of God says we are.

- And the constant attention to God and his memory: the presence of God for us in all moments of life, our relationship with him and gradually increases, leading to a strong connection. One of the five daily prayers wisdom, keep alive the remembrance of Allah during the night, in the heart of the believer.

- Due to the blessings and grace of God to man: If you look at your life, immerse yourself in the divine blessings, we will. To favor the creation philosophy is that man sitting right gift to remind the reader thanks to him, keep alive the remembrance of Allah in his heart closer. 
- Do well and avoid evil: good heart light and contrast, sin is dark heart page. Should strive to exercise the virtues, his heart brighter and avoiding sin, your love of God our discipline.

- Thinking about the purpose of creation: to review the personal beliefs about the spiritual, religious and existential, to look at the human ultimate concern.

- Search fundamental meanings of the situation and asking why and looking for connections between events, strengthening the spiritual intelligence.

At the end of this debate, we must say that spiritual intelligence can grow and strengthen the basis for all organizational stakeholders are better and more harmonious work life; a life free from any tension, fear and anxiety. Spiritual intelligence is also a way to escape from the responsibility of behaving strangely and becoming disabled person, but a way of life more joyful, incentivized and solemn responsibilities in the field of work and production.

\section{REFERENCES}

Emmons, R. A. (1999). The psychology of ultimate concern: motivation and spirituality in personality. New York: The Guilford Press.

Ghorbani, N. (2004). Spirituality experience is knowledge and modern cognitive to religion or a psychology constructing. Articles and studies Philosophy, 76(2), 69-98.

Harrisson, M., Loiselle, C. G., Duquette, A. and Semenic, S. E. (2002). Hardiness, work support and psychological distress among nursing assistants and registered nurses in Quebec. J Adv Nurs, 38(6), 584-91. https://doi.org/10.1046/j.1365-2648.2002.02225.x

Hurst, S. and Koplin-Baucum, S. (2005). A pilot qualitative study relating to hardiness in ICU nurses: hardiness in ICU nurses. Dimens Crit Care Nurs, 24(2), 97-100. https://doi.org/10.1097/00003465-200503000-00011

Kobasa, S. C. (1979). Stressful life events, personality, and health: an inquiry into hardiness. J Pers Soc Psychol, 37(1), 1-11. https://doi.org/10.1037/0022-3514.37.1.1

Kobasa, S. C., Maddi, S. R. and Kahn, S. (1982). Hardiness and health: a prospective study. J Pers Soc Psychol, 42(1), 168-77. https:// doi.org/10.1037/0022-3514.42.1.168

Lambert, V. A., Lambert, C. E., Petrini, M., Li, X. M. and Zhang, Y. J. (2007). Workplace and personal factors associated with physical and mental health in hospital nurses in China. Nurs Health Sci, 9(2), 120-6. https://doi.org/10.1111/j.1442-2018.2007.00316.x

Mabe, P. A. and Josephson, A. M. (2004). Child and adolescent psychopathology: spiritual and religious perspectives. Child Adolesc Psychiatr Clin N Am, 13(1), 111-25. https://doi.org/10.1016/S1056-4993(03)000919

McEwan, W. (2004). Spirituality in nursing: what are the issues? Orthop Nurs, 23(5), 321-6. https:/ / doi.org/10.1097/00006416-200409000-00008

Mitchell, D. L., Bennett, M. J. and Manfrin-Ledet, L. (2006). Spiritual development of nursing students: developing competence to provide spiritual care to patients at the end of life. J Nurs Educ, 45(9), 365-70.

Smucker, C. J. (1998). Nursing, healing and spirituality. Complement Ther Nurs Midwifery, 4(4), 95-7. https://doi.org/10.1016/S1353-6117(98)80040-1

Sortet, J. P. and Banks, S. R. (1996). Hardiness, job stress, and health in nurses. Hosp Top, 74(2), 28-33. https://doi.org/10.1080/00185868.1996.11736054

Vogt, D. S., Rizvi, S. L., Shipherd, J. C. and Resick, P. A. (2008). Longitudinal investigation of reciprocal relationship between stress reactions and hardiness. Pers Soc Psychol Bull, 34(1), 61-73. https://doi.org/10.1177/0146167207309197

Walker, M. J. (2006). The effects of nurses' practicing of the HeartTouch technique on perceived stress, spiritual well-being, and hardiness. J Holist Nurs, 24(3), 164-75. https://doi.org/10.1177/0898010105283343

Walt, V. and Alletta, E. (2006). A descriptive and exploratory study towards a spiritual intelligent transitional Model of organizational communication University of South Africa. J Nurs Res, 35(2), 273-80.

Wong, K. F. and Yau, S. Y. (2010). Nurses' experiences in spirituality and spiritual care in Hong Kong. Appl Nurs Res, 23(4), 242-4. https:/ / doi.org/10.1016/j.apnr.2008.10.002

Yang, K. P. (2006). The spiritual intelligence of nurses in Taiwan. J Nurs Res, 14(1), 24-35. https://doi.org/10.1097/01.JNR.0000387559.26694.0b 